\title{
REGIMENTO INTERNO DO PERIÓDICO COMUNICATA SCIENTIAE
}

\author{
CAPÍTULO I \\ Do periódico
}

Art. $1^{\circ}$ - Periódico Científico Comunicata Scientiae, é um periódico científico criado no Campus "Prof. a Cinobelina Elvas", em 2009, onde se encontra também sediado.

Parágrafo Único - A Comunicata Scientiae, é um periódico de caráter científico e sua administração passa ser regida pelo presente regimento.

\section{CAPÍ́tULO II}

Dos objetivos do periódico

Art. $2^{\circ}$ - O objetivo da Comunicata Scientiae é possibilitar a disseminação do conhecimento gerado pela comunidade científica nacional e internacional através da publicação de resultados de pesquisa e novas propostas científicas inéditas e relevantes para as Ciências Agrárias e Ambientais.

Parágrafo Único - Os trabalhos enviados para publicação deverão ser inéditos e atenderem a todas as exigências científicas e normativas em vigor à época.

\section{CAPÍTULO III \\ Da administração e estrutura editorial}

Art. $3^{\circ}$ - A administração da Comunicata Scientiae é composta por:

I - Conselho Editorial

II - Comissão Editorial

Parágrafo Primeiro - O periódico terá sua administrado acadêmica executada por um Conselho Editorial composto por 6 (seis) membros: um Editor Presidente, com mandato de 2 (dois) anos, e 5 (cinco) Editores Conselheiros, com mandato também de 2 (dois) anos, sendo permitido a recondução irrestritamente.

Parágrafo Segundo - Os membros a que se refere o caput do Art. $3^{\circ}$ serão pesquisadores dos seguintes grupos de pesquisa do CNPq, preferencialmente líderes:

a. Biodiversidade Animal do Semiárido;

b. Fruticultura no Vale do São Francisco (FRUTVASF);

c. FRUTAGRO - Grupo de Estudos em Fruticultura da UFPI.

Art. $4^{\circ}$ - O Editor Presidente será escolhido entre os membros do Conselho Editorial.

Parágrafo Único - A sucessão do Editor Presidente deverá ser aprovada por pelo menos quatro dos seis membros deste Conselho.

Art. $5^{\circ}$ - Um dos Editores Conselheiros será designado como secretário do Conselho Editorial.

Art. $6^{\circ}$ - O Conselho Editorial, indicará os integrantes da Comissão Editorial.

Parágrafo Primeiro - A Comissão Editorial será organizada com as seguintes categorias:

a. Editor-Chefe (preferencialmente um dos membros do Conselho Editorial);

b. Co-editor (preferencialmente um dos membros do Conselho Editorial); esses devem 
ser o elo de comunicação do periódico com o Conselho Editorial.

c. Editores Associados (Responsáveis por divulgar a revista em seu país de origem ou estado brasileiro, bem como submeter obrigatoriamente artigos ou revisões bibliográficas, com base na área de atuação;

d. Editores de Seção (responsáveis pela tramitação da avaliação dos trabalhos junto aos consultores Ad Hoc e parecer técnico do manuscrito);

e. Editor de Layout (Responsável pela verificação e correção das versões diagramadas antes da publicação);

f. Avaliadores ou Consultares Ad Hoc (responsável por emitir parecer técnico sobre o conteúdo das submissões);

g. Apoio técnico (Secretária, estagiários, revisores de idiomas e demais membros).

Parágrafo Segundo - A Comissão Editorial deverá ser composta por pesquisadores nacionais e internacionais, com ampla distribuição geográfica, com título de Doutor, não honorifico, exceto membros da equipe técnica.

Art. $7^{\circ}$ - São atribuições do Conselho Editorial:

a. Manter o alto padrão de qualidade cientííca;

b. Realizar atividades de pré-seleção dos trabalhos submetidos ao periódico ou designar editores específicos quando pertinente;

c. Direcionar os trabalhos aceitos em pré-seleção ao editor científico de área específica/correlata às respectivas submissões;

d. Manter atividades necessárias à atual indexação do periódico;

e. Elaborar metas e estabelecer prioridades de indexação do periódico em curto, médio e longo prazos;

f. Escolher os membros do Corpo Editorial;

g. Reunir-se periodicamente para avaliar os artigos e as condutas editoriais;

h. Elaborar e atualizar a política editorial;

i. Propor qualquer modificação de formato ou na estrutura do periódico;

j. Responsabilizar-se pelo processo de divulgação;

k. Providenciar relatórios anuais das atividades.

Art. $\mathbf{8}^{\circ}$ - São atribuições do Editor Presidente:

a. Representar o periódico em qualquer foro pertinente;

b. Presidir e convocar as reuniões do Conselho Editorial;

c. Indicar e nomear membros do Conselho Editorial para exercerem atividades específicas dentro do escopo de atuação que Ihe confere este Regimento:

d. Selecionar, indicar pessoal administrativo e científico, de acordo com as normas aqui expostas:

e. Zelar pelo cumprimento deste Regimento e demais normativas referentes à Comunicata Scientiae.

\section{CAPÍtULO IV}

\section{Das modificações deste regimento}

Art. $9^{\circ}$ - Este Regimento poderá ser modificado a qualquer momento por deliberação votada e aprovada pela maioria absoluta dos membros do Conselho Editorial e publicada junto a um número do periódico no sítio eletrônico. 


\section{CAPÍTULO $v$}

Disposições gerais e transitórias

Art. $10^{\circ}$ - Esta normativa e as demais estabelecidas a partir da publicação desta serão publicadas em seção própria junto a um número do periódico e estarão disponíveis no sítio eletrônico.

Art. $11^{\circ}$ - Os casos omissos neste regimento serão resolvidos pelo Conselho Editorial.

Art. $12^{\circ}$ - Esse regimento entra em vigor a partir da data de sua publicação, revogando-se quaisquer disposições contrárias e anteriores.

Bom Jesus (PI), 29 de setembro de 2017.

Guilherme Josée Bolzani de Campos Ferreira Editor Chefe da Comunicata Scientiae 